University of New Hampshire

University of New Hampshire Scholars' Repository

Languages, Literatures, and Cultures

Scholarship

Languages, Literatures, and Cultures

$1-1-2000$

\title{
The Politics of Happy Matrimony: Cerfvol's La Gamologie ou l'Education des Filles Destinées au Mariage
}

Nadine S. Berenguier

University of New Hampshire, Durham, nadine.berenguier@unh.edu

Follow this and additional works at: https://scholars.unh.edu/lang_facpub

Comments

Copyright @ 2000 Johns Hopkins University Press. This article first appeared in Studies in Eighteenth-Century Culture 29 (2000), 173-200. Reprinted with permission by Johns Hopkins University Press.

\section{Recommended Citation}

Berenguier, Nadine S. "The Politics of Happy Matrimony: Cerfvol's La Gamologie ou I'Education des Filles Destinées au Mariage," Studies in Eighteenth-Century Culture Nº 29 (2000): 173-200.

This Article is brought to you for free and open access by the Languages, Literatures, and Cultures at University of New Hampshire Scholars' Repository. It has been accepted for inclusion in Languages, Literatures, and Cultures Scholarship by an authorized administrator of University of New Hampshire Scholars' Repository. For more information, please contact Scholarly.Communication@unh.edu. 


\section{PROJECT MUSE}

The Politics of Happy Matrimony: Cerfvol's La Gamologie ou

l'Education des Filles Destinées au Mariage

Nadine Bérenguier

Studies in Eighteenth-Century Culture, Volume 29, 2000, pp. 173-200 (Article)

Published by Johns Hopkins University Press

DOI: https://doi.org/10.1353/sec.2010.0271

$\Rightarrow$ For additional information about this article https://muse.jhu.edu/article/267247/summary 


\title{
The Politics of Happy Matrimony: Cerfvol's La Gamologie ou l'Education des Filles Destinées au Mariage
}

\author{
NADINE BÉRENGUIER
}

$\mathrm{D}$

uring the early modern period, reading was understood by the Church and many educators as a problematic endeavor for women, especially the young and unmarried. Countless were the warnings against books as sources of possible disruption in the course of a woman's life. ${ }^{1}$ As a perceptive critic of his time, Molière debated the issue in some of his comedies, and in L'Ecole des Femmes, in particular, he caricatured the most reactionary positions on the dangers of reading for women, mocking Arnolphe's conviction that Agnès's absolute ignorance would guarantee the peace of their marriage. Conversely, in Les Femmes Savantes, he emphasized the privileged position that books and learning held on the "feminist" agenda, poking fun at three learned ladies, Philaminte, Bélise and Armande. In this querelle des femmes reignited by Molière, books and learning clearly played a central role.

As print culture expanded, and despite all the suspicion surrounding women readers, the entertainment and instruction of women came to depend more and more on books. During the sixteenth century (with Erasmus, Vivès, and Luther) women's education became an object of interest; in the seventeenth century, the adolescent girl who read made her debut in Grenaille's L'honnête fille (1639-40). ${ }^{2}$ In the eighteenth century, following the impulse given by François de Fénelon's Traité de l'Education des Filles (1687), many educators, from clerics to philosophes, fully recog- 
nized the necessity of a better education for girls. Not that they were immediately granted full access to all academic subjects. Abstract sciences like physics and mathematics were not encouraged; natural sciences were deemed just acceptable, and only the study of writing and history was unanimously recommended for girls. ${ }^{3}$ This new awareness justified the publication of a larger body of literature specifically designed for adolescent girls, chiefly instructional manuals on a variety of topics. ${ }^{4}$ The second half of the eighteenth century witnessed the significant expansion of conduct literature that provided young girls of marriageable age with social commentary and moral guidance. ${ }^{5}$

In Un Monde à l'Usage des Demoiselles, Paule Constant links the emergence of the social category called jeune fille with the rising awareness of educational needs. ${ }^{6}$ Caught between childhood (connected with animality) and womanhood (tainted by relations with a man), the female adolescent also stands on the threshold between the space of education (home or convent) and the space of the world (salon, theater, ball) from which she will access married life. The concrete and direct protections of the old space (convent walls or governess) must be replaced with more elusive and mediated defense mechanisms. As print culture prospered, female adolescence acquired a new escort in this passage from the old space to the new, an envoy from the space of the world, in the form of conduct books, agents of "le passage d'une civilisation orale, avec tout ce que cela comporte de traditions et de savoir-faire dont les femmes tiennent le dernier bastion, à une civilisation de l'écrit proprement masculine" (Un Monde, 16) [the transition from an oral culture with everything that includes in the way of traditions and skills which are still the province of women, to a print culture more properly male].

The ambiguous nature of the public for whom these books were intended generated inconsistencies worth investigating more closely. Because of the ambiguous status of their audience, for whom innocence was synonymous with ignorance, the authors of conduct books grappled with the difficult task of teaching candidates for marriage about the dangers of the world without threatening their modesty or reputation. As a result, these books somewhat uneasily walked a fine line between ignorance and awareness, between innocence and worldliness. In addition, if they wanted their handbook to reach its primary audience, these writers needed to secure the approval of the more experienced readers who would decide on the appropriateness of reading material. It is these difficulties, the need to preserve modesty while imparting worldly information and the need to target a variety of readers beyond the primary audience of adolescent girls, that give such manuals their particular flavor. 
Published in 1772 by the enigmatic Chevalier de Cerfvol, ${ }^{7}$ La Gamologie ou l'Education des Filles Destinées au Mariage illustrates this problem with an acute intensity. ${ }^{8}$ With his focus on conjugal life, Cerfvol is selfconsciously breaking a taboo. He presents his book as the Ur-text of a new and necessary branch of women's education: gamology, or the science of marriage. The text appears as a collection of seventeen letters (each with a title detailing its contents) sent by a man to his fifteen-year old charge, the orphan Sophie, before she leaves the convent where she has been raised. The Envoi, a letter in which he asks her permission to publish this private correspondence, announces his intention to "faire l'essai d'un nouveau genre d'éducation relative au mariage" (Envoi, 3) [attempt a new type of education about marriage]. Now that she has been happily married for six years and is the fulfilled mother of three healthy children, her guardian feels entitled to go public with his advice and to use her success for the edification of other young and ignorant ladies:

Presque toutes les filles, au moment qu'elles s'engagent, sont dans une ignorance absolue par rapport à ce qui peut constituer le bonheur dans le Mariage: on leur apprend à séduire, et jamais à se faire aimer. Voilà la source du mal: et la manière dont elles se comportent étant femmes, m'évite la peine de le prouver. (Envoi, 11)

[Almost all girls, when they get engaged, are in a state of absolute ignorance regarding what constitutes conjugal happiness: they are taught to seduce and never to invite love. Here is the source of the trouble. The behavior of married women proves my point.]

Cerfvol begins by admitting that men are partially to blame for this alarming ignorance: "Au reste, ma chère Sophie, cette foule de désordres qui trouble l'union conjugale n'est pas, à proprement parler, l'ouvrage de votre sexe; on peut nous l'imputer, comme à vous, puisque nous sommes les maîtres, ou plutôt les tyrans de l'éducation" (Envoi, 10). [Besides, my dear Sophie, this myriad of disorders which disturbs conjugal unions is not really the doing of your sex; we, as much as you, are to blame since we are the masters, or rather, the tyrants of education.] This admission gives his own project all the more urgency: it could even be a call to arms for more men to take into their own hands what mothers and other female educators have failed to achieve.

Cerfvol details Sophie's success not only in order to outline his major precepts but also to give this self-help manual more credibility: "Je m'aperçois qu'en suivant pied à pied le plan que je vous ai tracé, vous êtes parvenue sans effort, à la plus heureuse situation dont notre condition soit 
susceptible. Cette considération m'a fait résoudre à le publier: mais comme je ne l'avais rédigé que pour vous, j'ai besoin de votre aveu" (Envoi, 11). [I realize that in following the plan that I laid out for you, step by step, you were able to attain, effortlessly, the happiest possible situation. This consideration convinced me to publish my plan. But as I had written it only for you, I need your agreement.] Her effortless success is all the more commendable in that it provides an example for "les jeunes personnes de [son] sexe qui cherchent des modèles, ou qui veulent se corriger" (Envoi, 12) [young people of your sex in search of models or who want to improve themselves] and for "presque toutes les femmes" [almost all women] who will easily enjoy "un sort pareil au vôtre, quand elle le voudront; il leur suffit de vous imiter" (Envoi, 3-4) [a fate like yours, whenever they wish; all they need to do is follow your example]. Cerfvol empowers Sophie to change the private behavior of spouses and to pave the way for the salutary reforms needed to improve society at large.

Although Rousseau's name never appears in Cerfvol's text, one can trace a distinct lineage from Rousseau-the young woman's name is Sophie, after all-in regarding the private role of women as central to the wellbeing of society: as wives and mothers, they deserve a place in the polity. He thus focuses on these functions, often echoing the fifth book of Emile (1761) in his views on childrearing and on ways to keep a conjugal relationship happy and lasting. ${ }^{9}$ Their projects differ greatly, however, insofar as Cerfvol wants to make his advice directly available to a public of young women who were not the intended readers of his predecessor's treatise.

When Cerfvol elaborates on a detailed "politique du mariage" [conjugal politics], prescribing the behavior most likely to ensure the fidelity of a husband and the stability of matrimony, he is using two different and complementary meanings of the word politique: at the macro-political level, it refers to the repercussions of happy marriages on society at large; at the micro-political level, it refers to the wife's direct impact on the success of a conjugal relationship. ${ }^{10}$ In specifically addressing adolescent girls, Cerfvol emphasizes female responsibility at all levels:

Ceci est une leçon pour les deux sexes; mais je l'adresse plus particulièrement au vôtre parce que je le crois plus propre à achever l'importante affaire des rapports, d'où dépend le bonheur ou l'infortune des unions. Exemptes des sollicitudes que donnent la suite des principales affaires et la gestion des grandes Charges, les femmes sont plus à portée de descendre dans les détails qui nous échappent, de saisir les nuances de notre caractère: et parce qu'une éducation qui roule toujours sur la science des mots, et jamais sur celle des choses, n'a point encore gâté leur beau naturel, elles 
s'entendent mieux que nous à la négociation des tendres intérêts. (I, vii: 165-166)

[This is a lesson for both sexes; but I address it more particularly to yours because I think women are more adept at dealing with the important matter on which conjugal happiness or unhappiness depends. Exempt from the worries associated with the pursuit of important affairs and the management of influential offices, women are more able to go down into the details that escape us, to grasp the nuances of our character; and because beautiful nature has not yet been spoiled by an education that is always focused on the science of words and never on the science of things, they are better than we are at negotiating tender interests.]

Repeating the period's commonplace that women are more apt to shine in the realm of feelings, Cerfvol has them bear all the weight of the success or breakdown of a marriage. He recognizes the interactive nature of conjugal life, but he places all initiative in female hands and sees husbands as reacting to their wives' cues. As if responding to the contemporary champions of women's rights who incriminated men for their (legally unpunishable) infidelities and for other conjugal miseries, Cerfvol concludes with a complete exoneration of husbands:

Il faut savoir se rendre justice, ma chère Sophie. Quoi qu'on en dise, la préférence ne se donne jamais qu'à l'objet qui la mérite le plus, n'importe à quel égard. Pénétrez-vous de cette maxime et agissez en conséquence. Mais sur ce principe, que de femmes accusent la légèreté de leurs maris, et qui ne devraient accuser que leur propre conduite! (II, xiii: 119)

[One must be clearsighted, my dear Sophie. Whatever one may say, preference always goes to the object which deserves it most, in all respects. Make this maxim your own and act accordingly. But following this principle, how many women accuse their husbands for their inconstancy when they should blame their own conduct!]

This indictment of wives reasserts the fundamentally incriminatory logic of La Gamologie. Only by obeying the rules that Cerfvol alone dispenses will wives fulfill their conjugal responsibility: "Dans la Société, il faut un autre guide [que la nature]; quiconque s'y abandonnerait à l'instinct, trébucherait à chaque pas. Point de profession, point de rang, qui n'ait ses maximes, ses règles, sa politique" (II, xii: 95-96). [In society, one needs another guide (besides nature); those who would leave everything up to their instinct, would stumble at each step. There is no profession, no social rank that does not have its maxims, its rules, its politics.] Comparing the 
function of wife to a profession or a social rank implies, once again, that female behavior in marriage, because of its far-reaching implications, cannot be taken lightly.

At the macro-political level, Cerfvol's plan to bring marriage to a state of bliss enters into the discourse on population pervasive throughout the eighteenth century. The necessity of a large population was a widely accepted idea that found its way into the writings of Montesquieu, Diderot, and Rousseau, to mention only a few familiar names. ${ }^{11}$ And in many cases, a concern about depopulation went hand in hand with the defense of divorce (Rousseau was a notable exception): it was argued that the low fertility of unhappy marriages was detrimental to population growth and justified their dissolution in favor of happier relationships likely to bear more children. ${ }^{12}$ In its own way, La Gamologie participated in the heated debate on divorce that raged during the 1770s. Although he supported divorce, Cerfvol considered it a "remède violent qu'on applique à des maux plus violents encore" (I, i: 21) [a violent remedy applied to even more violent ills], and saw La Gamologie as a means to attack the problem at its root. By providing young women with a better knowledge of what to contribute to marriage and what to expect from it, his manual would lessen the need for divorce.

The concern about depopulation Cerfvol shared with many of his contemporaries was closely linked to a utilitarian view of marriage and of women's role in it:

Les femmes sont les dépositaires de l'espoir des générations; ce sont elles qui doivent perpétuer la première espèce d'êtres dont est formée la grande chaîne qui les comprend tous. Sorties des mains de la nature pour remplir ce vaste dessein, elles ne sauraient résister à la destination spéciale d'être mères, sans manquer aux conditions de leur existence; sans détruire, autant qu'il est en elles, le corps politique qui reçoit la force du plus grand nombre; sans trahir le vœu des familles qui les adoptent dans la vue de se propager; sans s'exposer enfin elles-mêmes aux plus terribles inconvénients causés par la surabondance ou le reflux des liqueurs propres à la génération et au développement des individus qui doivent prendre naissance dans leur sein. (II, xi: 53-54)

[Women are the trustees of the hope of generations; they must perpetuate the first species of beings who build the great chain of all beings. Molded by nature to fulfill this great project, they cannot give up their special destiny as mothers without denying the basis for their existence; without destroying, as much as it is in them, the political body which receives its strength from a large population; without betraying the wish of families 
who adopt them in order to have progeny; finally, without exposing themselves to the most terrible ailments caused by the superfluity or the reflux of liquids aimed at conceiving and developing the individuals who must be formed in their womb.]

Interestingly, the word dépositaire [trustee] refers to the legal notion of dépôt: it is a contract that explicitly does not entitle one of the contracting parties (the trustee) to the possession of the entrusted object, which must be returned in full when the depositor reclaims it. ${ }^{13}$ As a "contrat gratuit" [free contract], the "dépôt" is an irregular agreement: it lacks reciprocity (from which both parties would have something to gain) and is not negotiable (its conditions cannot be changed). It parallels the paradoxical structure of the early modern marriage contract which also deprived one of the parties (the wife) of her legal capacity and was also governed by a set of rules that could not be negotiated. Called a "contract" by the State, in opposition to the sacrament the Church saw in it, marriage gave a woman a social raison d'être while denying her any right to self-governance. The woman's role as a powerless trustee accounts, according to Carole Pateman in The Sexual Contract, for "the singular problems which arise about contracts to which women are a party." ${ }^{14}$ Cerfvol's insistence on the mother as a mere depository remarkably underscores the political meaning of childbearing and delineates her position at the junction of private and public interests:

Aussitôt qu'un enfant a pris l'être dans les flancs d'une femme, l'existence
de celle-ci acquiert une valeur qui est en raison doublée de ce qu'elle
était auparavant. . . Chargée volontairement d'un dépôt inappréciable,
et sur lequel la Société n'a pas moins de droits que la Nature, tout ce qui
tend à le détruire ou seulement à l'altérer, la rend coupable d'un crime
contre lequel les Lois ne sauraient assez déployer de vengeances. (II, xiv:
129; my emphasis)

[As soon as a child has come into being in the womb of a woman, her existence takes on a value which is in proportion doubled from what it was before. ... Because she is voluntarily entrusted with an invaluable charge over which Society has as many rights as Nature, anything that would destroy or alter it makes her guilty of a crime on which Laws could not wreak enough vengeance.]

Women's own value, increased (even doubled) by the precious "dépôt" they carry, can under no circumstances be transformed into power over that "dépôt." Although he does not mention abortion and infanticide ex- 
plicitly, Cerfvol makes it absolutely clear to women that once conception has occurred, they have no entitlement to their child and cannot dispose of it without committing a punishable crime. ${ }^{15}$ Voluntary infertility (i. e. contraception), which Cerfvol sees as plaguing the upper classes is, although less obviously condemnable, also branded as a despicable, vicious, and criminal act: "Et parce qu'elles n'évitent la grossesse que pour s'épargner quelques douleurs, quelques privations passagères, plus souvent pour se livrer avec plus de liberté à des penchants parmi lesquels le libertinage peut presque toujours être compté, nous joignons le mépris que mérite le vice, à la haine qui est due au crime" (II, xi: $65-66$ ). ${ }^{16}$ [And because they avoid pregnancy only to spare themselves some pains or temporary privations, and even more often to indulge more freely in activities which almost always include debauchery, we add (in our consideration of them) the scorn due to vices to the hatred due to crimes.] In his heated diatribes, Cerfvol denies to all women, regardless of their social origins, the right to control their reproductive life. Because if its impact on the whole social body, bearing children is in no way a private decision, but rather a civic obligation. ${ }^{17}$

Once the children are born, it continues to be the mother's responsibility to ensure their health and survival; on this topic as well, Cerfvol repeats the arguments which Rousseau and others brought forth in favor of maternal breast-feeding. ${ }^{18} \mathrm{He}$ congratulates Sophie for having given her own children this invaluable proof of devotion: "Voici le chef-d'œuvre de la conduite: vous les avez allaités: et que de biens découlent de cette utile occupation, de cette obligation indispensable des mères!" (Envoi, 5) [Here is the crowning example of your conduct: you breast-fed them. How many benefits result from this useful occupation, from this obligation mothers have to fulfill!] Breast-feeding is the most beneficial way to change woman's function in society: instead of being the simple "object" of desire and pleasure, she can be considered "sous le double point de vue de l'agréable et de l'utile" (II, xiv: 126) [under the double heading of pleasure and utility]. Not lingering on the well-known advantages for infants, he prefers to point out the benefits of breast-feeding for the conjugal relationship itself: "Elle [cette occupation] donne à l'époux ce degré de sécurité, sans lequel l'amour conjugal dégénère en une passion de peu de durée" (Envoi, 5). [It (this occupation) gives the husband that degree of security without which conjugal love degenerates into a fleeting passion.] It is the safeguard of marriage because it guarantees a husband's respect and esteem (II, xiv: 127), likely to last much longer than mere sexual attraction, which is only linked to fleeting pleasures. 
Although in the text as a whole, Cerfvol stresses the couple over the child, in its emphasis on the benefits of breast-feeding, La Gamologie belongs to the wave of handbooks on health, hygiene, and child-rearing published in the second half of the eighteenth century. ${ }^{19}$ Their glorification of motherhood had as corollary the necessity to place mothers under the competent authority of doctors and social reformers (like Cerfvol himself), prescribing their behaviors and feelings. These handbooks all displayed the hope that reforms would easily be implemented through a better management of human resources and contributed to what Michel Foucault has called "a dynamic racism, a racism of expansion." ${ }^{20}$ In his History of Sexuality, Foucault traces down the initial manifestations of what he calls the scientia sexualis to the Christian pastoral and the obligation to confess about the flesh. The diversification and fragmentation of this discourse which led, in the nineteenth century, to "an explosion of distinct discursivities which took form in demography, biology, medicine, psychiatry, psychology, ethics, pedagogy, and political criticism" $(H S, 33)$, had begun in the late eighteenth century. La Gamologie is a prime example of this explosion. What Foucault left unexplored in his seminal work-female sexuality-has been analyzed by Carole Pateman among others. In The Sexual Contract, she underscores women's position at the juncture of family and polity and shows the high stakes represented by their reproductive and educational roles. La Gamologie and the myriad of treatises like it provide a vivid illustration of her argument that sexuality is what justifies women's exclusion from civil society at the same time as it is their link to it.

Cerfvol's discourse on macro-political issues, however, must be adjusted to the pragmatic purposes of his handbook. His belief in the benefits to the social body of matrimonial happiness needs to be translated into more tangible principles, likely to bring about the necessary state of conjugal bliss. And it is at this micro-political level that he encounters the most difficulties. As he enters uncharted territories, he apparently fears that his pedagogical innovation will not be unanimously accepted. Because he targets a public for whom innocence is synonymous with ignorance, he is compelled to convey the innocuousness of his enterprise:

Je ne crois pas non plus que vous regardiez comme des atteintes données à votre pudeur, les détails dans lesquels je serai quelquefois obligé d'entrer sur la conduite réciproque des époux: vous savez trop le cas que je fais de cette vertu. D'ailleurs j'ai toujours pensé qu'une idée confuse, que des soupçons étaient plus capables d'exciter la rougeur sur un front ingénu, que la connaissance claire et distincte de la chose dont le fantôme fait rougir, et que c'est plutôt du choix des mots, que celui des sujets qu'on 
traite, que résultent la modestie et la candeur qui doivent caractériser tout ouvrage fait pour instruire. (I, ii: 43-44)

[I do not believe, either, that you will consider the details I will sometimes be obliged to mention about the reciprocal behavior of spouses as an attack on your modesty; you know too well in what high esteem I hold this virtue. Besides, I have always been of the opinion that confused notions and suspicions were more likely to make an innocent forehead blush than the clear and distinct knowledge of things, and the modesty and innocence suited to an instruction manual come from the choice of words rather than the choice of subjects.]

His concern about Sophie's modesty, highlighted by his insistence on the appropriate choice of vocabulary, refers to his discussion of the sexual component of marriage. Sexuality, as a field of scientific investigation with its own respectable (and not lewd) terminology, should not be judged inappropriate for young women: their happiness depends on their enlightenment. But his intent to present clear, distinct, and even scientific knowledge about sex points to the paradox which invariably appears when a young unmarried woman is the addressee: in order to respect her modesty and to preserve her innocence, he supposes on her part the prior knowledge of a linguistic code to which he never provides the key. This inconsistency implicitly acknowledges that more mature readers, those likely to decide on the appropriateness of the book's precepts for a young audience, will decipher the message.

Among these older readers, Cerfvol accuses the reluctant ones of retrograde obscurantism: "Un absurde préjugé a voulu, et cela dans le siècle le plus éclairé, que l'honneur fût attaché, dans les femmes surtout, à l'ignorance absolue des conditions d'une association qu'on ne peut rompre une fois qu'on l'a jurée" (I, ii: 41-42). [An absurd prejudice dictates, and this in the most enlightened of centuries, that honor especially for women results above all from the absolute ignorance of the conditions of an undissoluble union.] He is also quick to point out the deficiency of conventual education, since convents are places "où l'on ne connaît des hommes et du mariage que le nom; où la plupart des idées qu'on a du monde sont fausses" (I, i: 4) [where men and marriage are known only by name, where most ideas about the world are wrong]. In the first of the two letters focused on the "politique du mariage" [conjugal politics], Cerfvol transforms his critique of ignorance into a vocal indictment of all other attempts to teach about conjugal politics. He points his finger in various directions when answering the question "Who is to blame for women's ignorance?" 
L'éducation qui, je vous l'ai déjà dit, s'en tient à des termes trop vagues, trop généraux, à des notions trop obscures; qui, en un mot, n'en dit point assez sur cette importante matière. Nous avons quelques livres sur le sujet: ils ne vous apprennent presque rien, ou vous instruisent sur ce que vous devez ignorer. De ces Livres, les uns ne traitent que de ce qu'il y a de physique dans l'union des sexes, et ce ne sont pas les moins utiles: les autres n'insistent que sur les moyens de sanctifier l'union, et leurs Auteurs n'ayant qu'une vaine théorie de leur sujet, se sont contentés d'ajuster, comme ils l'ont pu, des maximes claustrales à l'état actif du mariage. Ils vous présentent une foule de motifs pour aider à supporter vos chagrins; il fallait vous donner des règles pour les éviter. . . L'éducation familière n'ajoute pas beaucoup à la science qu'on acquiert dans les Livres. Au moment où une fille va s'engager pour toujours, sa mère lui dit: Aimez votre mari, soyez sage, douce, complaisante, économe. Il y a longtemps, ma chère Sophie, que je vous ai dit toutes ces choses, et que je n'ai pas négligé d'y ajouter le comment et le pourquoi. (II, xii: 88-90)21

[Education which, as I already told you, has recourse to terms too vague and general, to notions too obscure; which, in short, does not talk enough about this important subject. We have a few books on the topic: they teach next to nothing or they teach you what you should not know. Among these books, some only deal with the physical aspect of the union of the sexes, and those are not the least useful; the others only dwell on the means to sanctify the union, and their Authors, with only an ineffectual grasp of their topic, do nothing more than to adapt claustral maxims to the active state of marriage. They present you a number of reasons to bear your sorrows; they should have given you rules to avoid them. . . Domestic education does not add much to the knowledge acquired in Books. When her daughter is about to be engaged for ever, her mother tells her: Love your husband, be faithful, kind, obedient, thrifty. I told you all these things a long time ago, dear Sophie, and I did not fail to add the how and the why.]

Cerfvol denigrates the oral transmission of skills and knowledge by mothers because of their inability to enlighten their daughters (assuming that "La Nature supplée à l'instruction" [II, xii: 92] [Nature supplements instruction ]). ${ }^{22}$ They, as much as their daughters, will profit from a tool which could help them break this damaging silence: "Et peut-être que notre correspondance, si elle devenait publique, formerait un plan d'éducation domestique que beaucoup de familles adopteraient" (I, vii: 168-69). [And maybe, if our correspondence became public, it would provide a plan of domestic education that many families would adopt.] But his uneasiness is most visible in his attacks on all the other books on marriage. The detailed 
account of their inadequacies, besides setting the stage for his own comments, betrays a fundamental need of justification vis-à-vis potential detractors. Why this fear of critics and this constant need of apology? Because Cerfvol perceives the uniqueness of his project-talking about conjugal sex to adolescent girls-as not just an asset but also a possible liability.

His fear of being branded as immoral is not unfounded. Nearly every letter in La Gamologie is sexually charged, with evocations of erotic yearnings or sexual activity. In the Envoi already, he alludes to the sexual harmony experienced by Sophie and her husband: "Entre vous l' amitié tempère les fougues de l'amour, et l'amour donne à l'amitié un caractère saillant qui l'empêche de se convertir en langueur" (Envoi, 6). [Between the two of you, friendship tempers the fire of love, and love gives friendship a salient character that prevents it from languishing.] How did he obtain this information about their intimacy? Nothing is said..$^{23}$

In his first two letters to Sophie, Cerfvol condemns celibacy (and, by the same token, the existence of convents and monasteries) as unnatural. He defines humans primarily as sexual beings and marriage as the only institution that allows sexual drives to be channeled properly. He leaves no ambiguity over what he sees as the main motive behind the human urge to marry:

Pour nous déterminer au mariage, sans réflexion, sans discussion de motifs, la main qui dirige l'Univers a attaché à l'union des sexes des plaisirs plus vifs, plus satisfaisants, des plaisirs d'une espèce supérieure à tous ceux qu'on peut éprouver dans quelque autre situation que ce soit: elle a voulu que l'acte qui prolonge notre existence, qui la perpétuera peut-être, fût le dernier terme de la félicité sensuelle; et qu'enfin le bonheur de deux Epoux bien assortis, l'emportât sur presque tous les autres genres de bonheur. (I, ii: 32-33)

[To convince us to marry, without reflection, without discussion of grounds, the hand that masters the Universe has endowed the union of the sexes with more vivid and satisfying pleasures, pleasures of a kind superior to those to be experienced in any other situation: it (the hand) has determined that the act that prolongs our existence, that will perhaps perpetuate it, is the highest point of sensual felicity; and that the happiness of two well-matched spouses is superior to almost any other kind of happiness.]

The third letter, concerned with the possible consequences of absolute paternal authority over marriage choices, once more keeps the debate in the sexual realm: Cerfvol discusses the legal distinction between fornica- 
tion and adultery, presenting the premature loss of female virginity ("fornication") — certainly a sign of moral weakness—as a less serious offense than adultery-a horrible crime with serious legal ramifications (I, iii: 64$65)$.

In the fourth letter, devoted to the issue of spouses' compatibility, Cerfvol discuss at length their "temperament" (i. e. sexual appetite). Even if compatibility of characters can be tested before marriage, how can a soon-tobe bride know the "temperament" of her future husband? This is a question he has difficulties answering. The following passage encapsulates the general problem faced by Cerfvol in his manual:

Il n'est plus temps de s'apercevoir de son erreur, sur le rapport des tempéraments, lorsqu'une fois on a donné sa main; et comment s'en assurer avant de s'engager? La conformation extérieure de votre Amant, vous dira quelque chose de sa complexion; sa conduite avec vous lorsque le hasard vous fera rencontrer sans témoins, vous en donnerait une connaissance plus étendue, si vous étiez assez sûre de vous-même pour le laisser entreprendre, sans rien craindre de sa témérité; mais l'essai est dangereux, et je vous l'interdis. (I, iv: 103)

[It is too late to realize one's mistake about the compatibility of temperaments once one has entered into marriage; but how to be sure before committing oneself? The exterior constitution of your fiancé will reveal something of his internal complexion; his conduct with you if, by chance, you were to meet without supervision, would give you more information, were you confident enough to let him be enterprising without fearing his temerity; but the test is dangerous and I forbid you to try it.]

Paradoxically, the prohibitory injunction which concludes the passage follows a rather detailed evocation of forbidden and risky behaviors. This passage underlines the lack of coherence that often plagues this text, bearing witness to its author's uneasiness with the assumed inexperience of his audience.

Interestingly, Cerfvol suggests premarital letter-writing as the safest way to guess a man's sexual appetite before the wedding night (with "temperament" translated into epistolary style), revealing much about the strong correlation he establishes between sexuality and writing:

Entrez plutôt en commerce de lettres: je vous le permets. Si les réponses de votre amant sont concertées, si elles sont bien écrites, si la raison y domine, celui qui les écrit est un homme froid. Si elles sont sans suite, sans liaison, si l'amour y répand sans symétrie son énergique bavardage, même dans les endroits les plus sérieux; si l'on s'y permet des expressions un peu hasardées, des tours hardis, si enfin elles sont souvent des 
chefs d'œuvres de déraison, elles sont dans le caractère des passions fortes; et les passions fortes ne naissent guère que dans un corps robuste. (I, iv: 103-104)

[Begin, rather, a correspondence: I allow it. If your lover's responses are logical, if they are well written, if reason is dominant, their author is a cold man. If they are irrational, disconnected, if love spreads its energetic chatter in them without symmetry, even in the most serious of passages; if he allows himself some risky expressions, bold accents; if, finally, his letters are often masterpieces of foolishness, then they are characteristic of strong passions, and strong passions can only arise in a robust body.]

If one applies this correlation to his own letters, one can definitely perceive in his frequent evocations of sexual pleasure what he himself calls "strong passions." His writing occasionally slips out of his control, as is revealed by the most suggestive passage of all:

Les préludes du plaisir suprême sont plus satisfaisants, enivrent l'âme de plus de volupté, que ce plaisir lui-même. Ils ont plus de durée; encore peut-on la [volupté] prolonger: disons tout; le désir leur survit, il les suit toujours. Tendres expressions, sentiments délicats, caresses affectueuses, coups d'œil ravissants, soupirs du cœur, élancement de l'âme, mouvements inconnus, palpitation universelle; toutes ces sensations affectent deux Amants; toutes sont distinctes, et par là plus voluptueuses. Mais enfin le moment arrive où, forcés de céder à l'impétuosité du feu qui les anime, au choc trop violent du sang qui bouillonne dans leurs veines, ils se précipitent dans les bras l'un de l'autre, et n'expriment plus que par leur silence qu'ils sont parvenus au dernier terme du bonheur. Alors tout est confondu pour eux. Ce n'est plus lui, ce n'est plus elle; c'est un couple qui ne sent plus rien de particulier; dont toutes les impulsions, toutes les sensations sont communes; dont toute l'attention est concentrée en luimême. (I, v: 124-125)

[The preludes to the supreme pleasure are more satisfying and intoxicate the soul more voluptuously than that pleasure itself. They [the preludes] last longer; so does sensual delight. Let us be clear: desire outlives them, it always follows them. Tender expressions, affectionate caresses, ravishing looks, delicate feelings, sighs of the heart, yearnings of the soul, unknown outbursts, universal palpitation; all these sensations affect the lovers; all are distinct, and thus more voluptuous. But finally the moment arrives when, forced to surrender to the impetuosity of the fire that drives them, to the violent shocks of the blood that boils in their veins, they rush into each other's arms, and express only through their silence that they have reached the highest degree of happiness. Then, everything is blurred 
for them. He is not he, she is not she any more; they are a couple who does not feel anything in particular; whose impulses and sensations are all shared; whose attention is all concentrated on itself.]

His choice of foreplay as the most pleasurable and intense part of the sexual act may be a concession to his pupil's age and a way to "protect" her from too risky behavior. This evocation, however, attests to the pleasure experienced by Cerfvol at initiating his young charge into all aspects of conjugal love, even if only through a text; in a passing remark at the beginning of the correspondence, he had expressed dismay at the thought that he might not be the first to depict pleasures "sur lesquels il n'est peut-être déjà plus temps d'éclairer votre cœur" (I, ii: 33) [about which your heart no longer need to be enlightened]. He abandons the scientific discourse that he claims to favor, and in a manual supposed to educate the young and innocent, such evocations could easily be deemed out of place. And they were. The Année Littéraire's reviewer, after praising the book's general usefulness for young women, expressed certain reservations about some of its parts: "Certains Lecteurs trouveront qu'il donne des tableaux trop animés des plaisirs de l'amour. ... Il me semble que ce n'est point là le langage qu'on doit parler à de jeunes personnes, en traitant des objets les plus sérieux de la vie." ${ }^{24}$ [Some Readers will find that he describes too vividly the pleasures of love.... It seems to me that this is not the language one should use in talking to young people about the most serious topics in life.] Remarkably, though, this reviewer does not seem to endorse fully this critical position, and, by mentioning "some readers" distances himself from it.

When, in the second part of the book, Cerfvol entitles one letter "De quelques branches de la politique du mariage" [On Some Branches of the Politics of Marriage], the formulas he proposes for keeping a husband faithful all revolve around the body and sexuality. A wife should avoid being approached by her husband during what he calls "accidents naturels" (II, xiii: 103) [natural accidents] or after having given birth, as these situations leave "impressions désagréables" [disagreeable impressions] on him (II, xiii: 107). For the same reason, she should never be careless of herself in the privacy of her home while being a slave to fashion in public (II, xiii: 112). He insists on the regular use of baths, since hygiene is necessary for her health and attractiveness. If, however, a husband discovered some imperfections, his wife would need to deploy all her charms to distract him: "Pour l'en détourner, éblouissez-le par des beautés neuves, séduisantes par leur manière d'être offertes, livrez-vous subitement à la volupté de votre âge pour l'y plonger à son tour et distraire son attention d'un objet 
qui mélange sa félicité, qui affaiblit en lui l'idée d'une jouissance parfaite" (II, xiii: 118). ${ }^{25}$ [To distract him, dazzle him with renewed charms that you will offer in a seductive way, give yourself suddenly to the sensual pleasures of your age in order to immerse him in them as well and make him forget that which could mitigate his happiness and weaken his idea of a perfect enjoyment.] These suggestive prescriptions, intended to eradicate the ignorance he deplores, are mitigated by occasional refusals to elaborate further on a particular topic. For example, although he insists that women should be aware that "la nature [leur] interdit quelquefois les plaisirs" (II, xiii: 117) [nature sometimes denies (them) pleasures], he remains silent about what these moments are exactly, and assumes Sophie has knowledge of facts he never clarifies.

These patterns of incoherence in La Gamologie are certainly what motivate the Journal Encyclopédique's reviewer to qualify his praise of an otherwise very commendable project. The critic calls attention to the fact that young readers will have difficulties understanding some of the principles without any help:

Cet ouvrage est écrit avec chaleur, et profondément pensé; mais destiné aux jeunes personnes qui se lieront par le mariage, cette teinte de philosophie sera-t-elle à leur portée, et saisiront-elles les préceptes et les conséquences au premier coup d'œil? C'est le manuel de leur état; excellent en lui-même, nous serions fâchés qu'un vernis, peut-être trop scientifique, nuisît aux avantages que le zèle de l'auteur a droit d'en attendre. ${ }^{26}$

[This book is written with passion, and profoundly thought through; but being addressed to young people who are entering into marriage, does it have too much philosophy to be accessible to them and will they understand the precepts and consequences at first sight? This is the manual of their condition; excellent in itself, it would be a shame if its too scientific varnish were to annihilate the advantages that the zeal of its author is entitled to expect.]

One should not forget that the word philosophie, traditionally referring to scientific knowledge, acquired anti-religious connotations during the eighteenth century and became associated with the critique of social and political institutions. Because of the clandestine means used by some philosophes to disseminate their ideas, "philosophique" also became synonymous with subversive and pornographic. ${ }^{27}$ Many of these trends come together in Cerfvol's reformist ambitions: his predilection for sexual evocations is a way to express his mistrust of tradition (the religious tradition in particular) and becomes the symbol of his absolute faith in new forms of knowl- 
edge. Cerfvol's pleasure in sharing knowledge about sex brings to light one of Foucault's idées maittresses: "We have at least invented another kind of pleasure; pleasure in the truth of pleasure, the pleasure of knowing that truth, of discovering and exposing it, the fascination of seeing and telling it, of captivating and capturing others by it, of confining it in secret, of luring it out in the open-the specific pleasure of the true discourse on pleasure" ( $H S, 71)$. Grounded in the need for a sciencia sexualis, La Gamologie becomes an ars erotica in which "truth is drawn from pleasure itself, understood as a practice and accumulated as experience" $(H S, 57)$. Many of the text's problems stem from the dual nature of its discourse, caught between sciencia sexualis and ars erotica.

Cerfvol does not forget, however, that he is addressing young female readers; he does spend a great deal of energy convincing them of the need to control their behavior. One of his favorite topics is the inadequacy of love in marriage, echoing Rousseau's character Julie after her wedding to Wolmar and Emile's preceptor after the union of Emile and Sophie..$^{28}$ Passionate love, because of its intense and precarious nature, cannot be the basis of a solid relationship. Between the heat of passion (incompatible with domestic duties) and the coolness of indifference (unfulfilling and detrimental to procreation), spouses must find "le point du Thermomètre, qui convient précisément en ménage" (Envoi, 6) [the point of the Thermometer that is exactly suitable to domesticity]. This ideal balance can only be achieved through friendship: "Et ce qu'on tient uniquement de l'Amour, le Mariage souvent le fait perdre. C'est l'amitié, c'est l'estime qu'il faut essayer de fixer dans cet état, et ces sentiments supposent le respect" (I, iii: 56-57). ${ }^{29}$ [And what Love provides is often lost in Marriage. Friendship and esteem must be the base of the conjugal state and these feelings go hand in hand with respect.] And in order for friendship to be secured between spouses, attention must be paid to the compatibility of their characters. Even in arranged marriages (which he accepts as a necessity), one should not ignore the "convenances de l'esprit, du cœur, des tempéraments, des goûts, etc." (I, ii: 49) [the conformity of mind, of heart, of temperaments, of tastes]. This leitmotiv - the unreliability of love as opposed to the strength of friendship--is hardly surprising in a book addressed to readers who are believed to be prey to their own unbridled imaginations and, as such, attached to false notions of love and marriage. ${ }^{30}$ Only through the careful management of their own feelings and desires can they avoid the many disillusionments that often follow the high expectations of the prenuptial period.

What friendship is in the emotional realm ("le moral"), moderation is in the sexual ("le physique"). Regardless of the spouses' "temperaments," the 
basic rule governing sexual activity (especially at the beginning of marriage) must be restraint:

La satiété ressemble aux privations absolues et produit les mêmes effets: d'abord le dégoût, puis l'engourdissement, enfin l'impuissance de sentir. Oui, ma chère Sophie, comme tous les autres sens, l'imagination se blase et se déprave. Multiplier les plaisirs, c'est en abréger la durée. Ceux du mariage sont specialement du nombre de ceux dont on doit user sobrement, puisqu'ils ne se communiquent et ne se ressentent qu'en altérant sensiblement les principes qui les produisent, et l'imagination qui les apprécie. (I, v: 113) $)^{31}$

[Satiety resembles absolute privations and has similar effects: first disgust, then torpor, and finally the inability to feel. Yes, my dear Sophie, like all the other senses, imagination becomes blunted and depraved. By multiplying pleasures you shorten their lifespan. The pleasures of marriage in particular belong to those which must be used sparingly, since they are communicated and felt only through the alteration of the principles that produce them and of the imagination that perceives them.]

In his numerous reminders of this important precept, Cerfvol argues that moderation not only maintains the husband's interest in his wife since "les dégoûts qui suivent d'une jouissance habituelle et trop répétée, s'emparent plutôt de notre sexe que du vôtre" (I, v: 117) [our sex is more likely than yours to fall prey to the disgust that follows an enjoyment too often repeated], but also preserves the health of their future offspring, which depends on "la manière dont leurs Auteurs ont su régler l'usage de leurs passions" (I, v: 127) [the way in which their Genitors were able to control the use of their passions].

Both his praise of friendship and his exhortation to moderation represent a concerted effort to control female sexuality. Male sexuality, because of the physical limitations "nature" has placed on the male sexual drive, is easier to restrain: "Cette sage Mère [Nature] a plus fait; elle a voulu que les organes de la volupté ne répondissent pas toujours aux velléités passagères qu'excite en nous une imagination échauffée par la présence de l'objet dont nous sommes épris" (I, v: 118-19). [This wise mother (Nature) has done more; she decided that the organs of pleasure should not always respond to the momentary desires excited in us by an imagination heated by the presence of the object of our love.] Female modesty ("pudeur"), therefore, is not a social construct ("l'effet d'une loi humaine" [the result of a human law]) but "une institution de la prévoyante Nature" [an institution of prudent Nature] not to exhaust the limited resources of men who are then "en état de triompher plus complètement" (I, v: 118-19) [able to triumph more completely]. Cerfvol reiterates some of the period's convic- 
tions regarding the unlimited sexual drive of women which is spurred on by their overheated imagination and only kept in check by modesty. ${ }^{32}$ Even if his discourse on self-control strives to mitigate the suspicion generated by his pervasive use of sexual evocations, it remains very erotically charged.

The scientific (or "philosophique") knowledge Cerfvol proposes in $L a$ Gamologie is the antithesis of the "notions confuses" [confused notions] inculcated in adolescent girls by domestic and conventual education. On matters of conjugal politics as well as child-rearing, Cerfvol, substituting the authority of books for the oral transmission of knowledge, denies that older women might have any valuable insights and skills: nuns, being celibate, are in no position to teach girls about marriage and children; mothers and governesses, bad examples in most cases, are ill-equipped to convey knowledge about what they do not know themselves; wetnurses are useless as well because they are "asservies aux vieilles coutumes" [enslaved to old customs] and "incapables de les corriger" [unable to change them] (II, xv: 147). Under such circumstances, and until the generation enlightened by La Gamologie can fully implement its invaluable advice, only books can be trusted as a source of guidance. In defending his strong faith in the power of books, Cerfvol even begs to differ with Rousseau on the questions of reading and theater-going, arguing that "les spectacles conviennent mieux à une jeune personne, qu'ils ont plus d'empire sur son esprit, que n'en ont les livres, parce que les sujets y sont en action" (I, viii: 193) [spectacles, because they rely on action, are better suited for a young woman and that they have more influence on her mind than books].

His praise of books (and spectacles) is one more example of his general conviction that, in a society which is in great need of reform, experience and example have no validity. In this matter, once again, Cerfvol's confidence is occasionally undermined by his incoherence. For instance, before dispensing his recommendations on child-rearing (ranging from swaddling to moral education) in the last two letters, he expresses serious doubts about the usefulness of educational handbooks: their principles, valid for a particular child or young person, cannot do justice to the great diversity of children's characters and "complexions." ${ }^{33}$ These views, in stern opposition to his optimistic plea for imitation in the Envoi, call into question the very manual he himself is writing, in which advice addressed specifically to Sophie must provide the formula for the success of all the unknown young women who will make up its audience. ${ }^{34}$

La Gamologie's ambiguities and paradoxes stem from Cerfvol's difficulties in fitting his text to the needs of his readers, female adolescents. There is no doubt, judging from his obviously deep conviction as to marriage's political role in society, that Cerfvol wants to convince adolescent girls that they, as future wives and mothers, are key figures in neces- 
sary social reforms ${ }^{35}$ But they are in no way the only readers he is addressing. He knows that, before reaching the likes of Sophie-not every girl is an orphan - his handbook will have to undergo the scrutiny of other readers, and they are the ones to whom he must justify his project. Among those readers, as the first beneficiaries of his advice, he includes mothers who, after reading his book, should be better equipped to enlighten their daughters on conjugal matters. His repeated disclaimers and justifications attempt to win them to his cause, but his frequent attacks against them do certainly not secure him a receptive audience. His harsh criticism complicates his task tremendously.

Cerfvol may be addressing women but he does not want to hear them. He silences Sophie (since no letter actually requires her reply, her voice is never heard) as well as all the women (sources of bad advice) who have come or may come in contact with any adolescent girl. Sophie's presence in the text is secured through her body-source of measured pleasure for her husband and of nurture for her children. The omnipresence of her domesticated body suggests the existence of yet another set of readers, those for whom Cerfvol develops his socio-political theory of marriage and whom he calls "les maîtres, ou plutôt les tyrans de l'éducation" (Envoi, 10) [masters, or rather tyrants of education]. In order to convince them that the improvement of women's education is in their best interest and can remain under their control, he enlists the seductive character of Sophie, raising the point that Nancy K. Miller brings up in her article "II's' in Drag: the Sex of Recollection." Talking about eighteenth-century male novelists disguised as heroines, she argues that "the assumption of the Other's sexual identity through an ' $I$ ' in drag constitutes an exemplary-if extreme-model of the erotics of authorship in the eighteenth-century novel: a mode of production calibrated not so much to seduce women readers as to attain recognition from other men." ${ }^{36}$ Cerfvol does not disguise himself as his heroine, but the colossal self-importance and self-satisfaction he expresses over Sophie's conjugal success makes him into a Pygmalion-like figure who molds the ideal modern woman and then holds her up as a trophy to show other men. Paradoxically, the male gatekeeper of education whose primary concern is of course to safeguard the innocence of his unmarried female charge, can maybe be distracted with a little titillation aimed directly at her. With the convenient expedient of Sophie as, at once, the stand-in addressee for all young women readers and the sexually and domestically idealized successful wife, with whom Cerfvol is actually carrying on a veiled flirtation, a little bit of book sex or at the very least epistolary foreplay, La Gamologie can hope to slip past its pruriently interested male censors into the hands of the young women who need it most. 


\section{NOTES}

1. Both Fénelon and Maintenon, who advocated women's education, emphasized the importance of selecting carefully what girls should be allowed to read. For more details on their opinions about the pernicious effect of books, see Nadine Bérenguier, L'Infortune des Alliances: Contrat, Mariage et Fiction au Dix-Huitième Siècle, Studies on Voltaire and the Eighteenth Century, Vol. 329 (Oxford, 1995), 311-12.

2. The fashion of honnêteté manuals lasted a few decades, following the publication of Faret's L'Honnête Homme ou l'Art de Plaire à la Cour (1630) and Du Bosq's L'Honnête Femme (1632 and 1636). In addition to his L'Honnête Fille, François de Grenaille published L'Honnête Mariage (1640) and L'Honnête Garçon (1642).

3. This brief summary cannot do justice to the diversity of eighteenth-century opinions on the subject. For a more detailed account see Comte de Luppé, Les Jeunes Filles à la Fin du Dix-Huitième Siècle (Paris: Librairie Champion, 1925), 139-71.

4. See Appendix 1. Some of these books are discussed by the Comte de Luppé in Les Jeunes Filles à la Fin du Dix-Huitième Siècle, 139-71.

5. In the first half of the century, Lambert's Avis d'une Mère à sa Fille, published in 1727 , became extremely popular, but the vast majority of conduct books appeared in the second half of the century. See Appendix 2.

6. Un Monde à l'Usage des Demoiselles (Paris: Gallimard, 1987), 14. A fille is an unmarried woman, and a jeune fille is still young while a vieille fille has passed her prime. The French term jeune fille is actually difficult to translate into English: a young woman may be married and a young lady indicates a high social rank but I will nonetheless use the terms in the context of this paper. I will also introduce the term adolescent girl since it was known in the eighteenth century (Cerfvol himself makes use of it).

7. Not much is known about the identity of the person (or persons?) publishing under the name Cerfvol, although he is mentioned in some of the historical studies I used: Luppé's Les Jeunes Filles à la Fin du Dix-Huitième Siècle, Jocelyne Livi's Vapeurs de Femmes. Essai Historique sur Quelques Fantasmes Médicaux et Philosophiques (Paris: Navarin, 1984), Paul Hoffmann's La Femme dans la Pensée des Lumières (Paris: Editions Ophrys, 1977), James Traer's Marriage and Family in Eighteenth-Century France (Ithaca, London: Cornell University Press, 1980). The mystery of his identity is confirmed by Alfred Sauvy in "Quelques démographes ignorés du XVIIIe siècle: de la Morandière, de Caveirac, Cerfvol, Pinto,” appendix to Joseph Spengler, Economie et Population. Les Doctrines Françaises avant 1800. De Budé à Condorcet (Paris: Presses universitaires de France, 1954), 368-71.

8. La Gamologie ou l'Education des Filles Destinées au Mariage: Ouvrage dans Lequel on Traite de l'Excellence du Mariage, de son Utilité Politique et de sa Fin, et des Causes qui le Rendent Heureux ou Malheureux (Paris: Veuve Duchesnes, 1772). All references in the text indicate the part, the letter and the page. In North 
America, the text is available in the microfilm collection History of Women, Reel 20 no. 125, Schlesinger Library, Harvard University.

Cerfvol deplores not having been able to raise Sophie himself to prepare her better for her future: "Si nos mœurs eussent permis que je veillasse sur votre enfance, et que votre éducation eût été mon propre ouvrage, la chose serait moins ambarrassante: ayant vécu dans le monde, vous le connaîtriez" [If our customs had allowed me to supervise your childhood, and your education had been my own doing, this would be less awkward: having lived in the world, you would know it] (I, i: 3).

9. Cerfvol is attempting to implement what Rousseau deemed unique to Emile and Sophie's relationship:

J'ai souvent pensé que si l'on pouvait prolonger le bonheur de l'amour dans le mariage, on aurait le paradis sur la terre. Cela ne s'est jamais vu jusqu'ici. Mais si la chose n'est pas tout à fait impossible, vous êtes bien dignes l'un et l'autre de donner un exemple que vous n'aurez reçu de personne, et que peu d'époux sauront imiter. Emile, ou de l'Education, 4 vols. (Paris: Bibliothèque de la Pléiade, Gallimard, 1964), 4: 861.

[I have often thought that if one could prolong the happiness of love in marriage, one would have paradise on earth. Up to now, that has never been seen. But if the thing is not utterly impossible, you both are quite worthy of setting an example that you will not have been given by anyone and that few couples will know how to imitate.] Emile or On Education, trans. Allan Bloom (New York: Basic Books Inc., 1979), 476.

10. He entitles letter xii "De la politique du mariage" and letter xiii "De quelques branches de la politique du mariage," but they are not the only letters prescribing rules of conjugal happiness.

11. Montesquieu, Lettres Persanes (Paris: Garnier-Flammarion, 1964), cxxii: 195-96; Diderot, Supplément au Voyage de Bougainville (Paris: Bibliothèque de la Pléiade, Gallimard, 1951), 982; Rousseau, Emile, 256. In the Encyclopédie, the article "Population" also underlined its significance for a state, even if its author, d'Amarville, did satirize the alarmist theories of Wallace. Encyclopédie ou Dictionnaire Raisonné des Sciences, des Arts et des Métiers (1751-1772; StuttgartBad Connstatt: Friedrich Frommann Verlag, 1966), vol 13. Cerfvol himself wrote a Mémoire sur la Population (London, 1768). For an overview, see Yvonne Knibielher and Catherine Fouquet, Histoire des Mères du Moyen Age à nos Jours (Paris: Montalba, 1977), 144.

12. In the late 1760 s and in 1770 , Cerfvol published pamphlets on divorce: Législation du Divorce (London, 1769); Intérêt des Femmes au Rétablissement du Divorce (Amsterdam, 1770); Le Parloir de l'Abbaye de *** ou Entretiens sur le Divorce par M. de $V^{* * *}$ Suivi de son Utilité Politique (Geneva, 1770). Other champions of divorce were Montesquieu, Diderot, Voltaire, d'Helvétius, d'Holbach, Toussaint, and d'Antraigues. See Traer, Marriage and the Family in Eighteenth- 
Century France, 76-78; 105-36. For a more complete history of divorce, see Roderick Phillips, Putting Asunder: A History of Divorce in Western Society (Cambridge: Cambridge University Press, 1988) as well as his Untying the Knot: A Short History of Divorce (Cambridge: Cambridge University Press, 1991). Also useful is the anthology of eighteenth-century pamphlets edited by Colette Michael: Sur le Divorce en France. Vu par des Ecrits du Dix-Huitième Siècle (Genève; Paris: Editions Slatkine, 1989).

13. According to the lawyer Claude-Joseph de Ferrière, a dépôt is "un contrat par lequel on donne quelque chose à garder à quelqu'un, à la charge de la rendre toutefois et quantes il plaira à celui qui l'a déposé. Ce contrat est gratuit, et ne transfêre aucune propriété, ni la véritable possession. On ne permet donc point au dépositaire de la chose déposée de s'en servir; mais on lui en commet seulement la garde" (Article "Dépôt") [a contract by which one gives something to someone for safekeeping, with the stipulation that it be returned whenever the one who deposited it chooses. This contract is free, and does not involve the transfer of any claim, nor of actual possession. The trustee, therefore, is not given permission to use the thing which has been deposited; he is only responsible for its safekeeping], Dictionnaire de Droit et de Pratique, contenant l'Explication des Termes de Droit; d'Ordonnnances, de Coutumes et de Pratique: avec les Juridictions de France (Paris, 1740).

14. Carole Pateman, The Sexual Contract (Stanford: Stanford University Press, 1988), 5. For a detailed analysis of the concept of dépôt see Bérenguier, L'Infortune des Alliances, 345-73.

15. Largely committed by women living in poverty or giving birth to illegitimate children, infanticide was a widespread practice in the eighteenth century. In addition, the very high mortality rate among foundlings made the abandonment of infants a sort of infanticide. See Olwen Hufton, The Poor of Eighteenth-Century France, 1750-1789 (Oxford: Oxford University Press, 1974), 321-22; 329-51.

16. Sterility is not only a social consequence of debauchery but also a physical one:

Les jouissances prématurées, ou excessivement répétées, l'usage immodéré de toutes les espèces d'aliments, des liqueurs spiritueuses, les plaisirs atténuants des veilles, ceux plus destructeurs encore auxquels un célibat forcé semble avoir donné naissance, et qui jetant la nature dans de perpétuelles illusions, en énervent les ressorts: voilà les causes majeures de la stérilité si rare dans les campagnes; et si commune dans les villes (II, xi: 66-67).

[Premature or excessively repeated sensual pleasures, the excessive use of all kinds of foods and of spirits, the extenuating pleasures of sleepless nights, the even more destructive pleasures engendered by forced celibacy, and which, by providing nature with constant illusions, enervate its resources: here are the major causes of infertility, so rare in rural areas and so frequent in cities.] 
17. Jaucourt's article "Fausse-couche" in the Encyclopédie establishes the strong link between individual and collective responsibility: "Le sujet n'est pas moins digne de l'attention du législateur philosophe que du médecin physicien. ... Comment parer aux avortements? C'est en corrigeant les principes qui y conduisent; c'est en rectifiant les vices intérieurs du pays, du climat, du gouvernement dont ils émanent." [This matter is as worthy of the attention of the legislator-philosopher as it is of that of the doctor-physician... . How to prevent abortions? By changing the principles that lead to it; by correcting the vices fostered by a particular country, climate, and government.] Encyclopédie ou Dictionnaire Raisonné des Sciences, des Arts et des Métiers, vol. 6.

Of interest in this context is Cerfvol's proposal that the state help poor women fulfill their maternal duty through subsidies, a welfare system avant la lettre. He does not elaborate any detailed plan, but clearly recognizes the constraints that economics place on women in poverty. The reaction of the Journal Encyclopédiques reviewer is revealing of the novelty of such a proposal: "Cette idée est frappante: c'est aux administrateurs de ces maisons [foundling hospitals] à l'apprécier." [This is a striking idea: now it is up to the administrators of these foundling hospitals to take it up.] Journal Encyclopédique, dédié à son Altesse sérénissime ME Mgr. le Duc de Bouillon, Grand Chambellan de France, vol. 2, part 3 (March 1773): 446. Olwen Hufton, addressing poverty in general, does not provide much information on this issue, but her findings suggest that help of that nature was not a priority. See Poor of Eighteenth-Century France, 131-216.

18. A reminder of the famous advice to mothers: "Mais que les mères daignent nourrir leurs enfants, les mœurs vont se réformer d'elles-mêmes, les sentiments de la nature se réveiller dans tous les cœurs; l'Etat va se repeupler: ce dernier point, ce point seul va tout réunir. L'attrait de la vie domestique est le meilleur contrepoison des mauvaises mœurs" (Emile, 258). [But let mothers deign to nurse their children, morals will reform themselves, nature's sentiments will be awakened in every heart, the state will be repeopled. This first point, this point alone, will bring everything back together. The attraction of domestic life is the best counterpoison for bad morals] (Bloom, 46).

Although few hygiene handbooks were written by women, Marie Anel Le Rebours, in 1767, published the very popular Avis aux Mères qui Veulent Nourrir leurs Enfants "which was endorsed by Samuel Tissot, the enlightened Swiss doctor, as well as by the Faculty of Medicine of Paris" and "represents a practical guide to infant care and nursing written by a midwife for women themselves." Mary Jacobus, "Incorruptible Milk: Breast-feeding and the French Revolution," in Rebel Daughters. Women and the French Revolution, ed. Sara Melzer and Leslie Rabine (New York, Oxford: Oxford University Press, 1992), 60.

19. Jean-Charles Desessartz, Traité de l'Education Corporelle des Enfants en Bas Age, ou, Réflexion Pratique sur les Moyens de Procurer une Meilleure Constitution aux Citoyens (Paris, 1760); Samuel Auguste David Tissot, Avis au Peuple sur sa Santé (Lausanne, 1761); Joseph Raulin, De la Conservation des Enfants (Paris, 1767); Alphonse Leroy, Recherches sur les Habillements des Femmes et des Enfants (Paris, 1772); William Buchan, Médecine Domestique (London, 1775). 
They combined medical and hygienic advice with educational principles. More information can be found in Jacques Donzelot's The Policing of Families (New York: Pantheon Books, 1979), 9-47 and Yvonne Knibielher and Catherine Fouquet's Histoire des Mères, 144-46.

20. Michel Foucault, The History of Sexuality. Volume I: An Introduction, tr. Robert Hurley (New York: Vintage Books, 1980), 125. Subsequently cited as $H S$.

21. Cerfvol does not mention a single title, but one book he may be alluding to is Nicolas Venette's Le Tableau de l'Amour Conjugal (1687), which had fifty subsequent reeditions and was in print until the middle of the twentieth century.

22. In addition to what $I$ have already quoted, other passages reiterate similar complaints: I, ii: 3-9, 12-15; vii: 168; viii: 207; II, xii: 91-93.

23. Similarly, Cerfvol evokes the perfect balance Sophie's parents had found in their sexual life, foreshadowing Sophie's own harmonious marital intimacy. Like Sophie and her husband they "ne s'y livraient [au plaisir] que lorsqu'avertis par leurs sens ils se trouvaient assez d'exigence pour la communiquer [l'exigence], ou lorsque la volupté, cette souveraine impérieuse des âmes délicates, ne leur permettait plus de résister à son attrait" (I, v: 132) [They surrendered to pleasure only when, warned by their senses, their need was so great that they had to communicate it, or when sensual delight, that powerful queen of delicate souls, no longer allowed them to resist her charm.] He never indicates how and why he obtained such private details.

24. Année Littéraire vol. 5, lettre ix (1772): 213.

25. According to Livi, this kind of advice turns a wife into a prostitute: "Pour faire oublier son imperfection, la femme mariée est autorisée à tenir un nouveau rôle: celui de la prostituee" (Vapeurs de Femmes, 31). [In order to cover her imperfection, the married women is permitted to take a new role: that of the prostitute.]

26. Journal Encyclopédique vol. 2, part 3 (1773), 446.

27. Robert Darnton, The Forbidden Best-sellers of Pre-Revolutionary France (New York : W. W. Norton, 1995).

28. Julie explains to Saint-Preux:

"Ce qui m'a longtemps abusee, et qui peut-être vous abuse encore, c'est la pensée que l'amour est nécessaire pour former un heureux mariage. Mon ami, c'est une erreur; l' honnêteté, la vertu, de certaines convenances, moins de conditions et d'âges que de caractères et d'humeurs, suffisent entre deux époux; ce qui n'empêche point qu'il ne résulte de cette union un attachement très tendre qui, pour n'être pas précisément de l'amour, n'en est pas moins doux et n'en est que plus durable." Julie ou la Nouvelle Héloise (Paris: Bibliothèque de la Pléiade, 1961), vol. 2: 372.

["The thing that long deluded me and perhaps still deludes you is the idea that love is essential to a happy marriage. My friend, this is an error; honesty, virtue, certain conformities, less of status and age than of character and humor, suffice between husband and wife; that does not prevent a very tender attachment from emerging from this union which, without 
exactly being love, is nonetheless sweet and for that only the more lasting."] Julie, or the New Heloise, trans. Philip Stewart and Jean Vaché, vol. 6 of The Collected Writings of Jean-Jacques Rousseau (Hanover and London: University Press of New England, 1997), 306.

Emile's preceptor also enjoins the newly wedded Emile and Sophie to become friends: "Quand vous cesserez d'être la maîtresse d'Emile vous serez sa femme et son amie; vous serez la mère de ses enfants" (Emile, 866). [When you stop being Emile's beloved, you will be his wife and his friend. You will be the mother of his children] (Bloom, 479).

29. He often pleads against love and for friendship: Envoi, 5, 9; I, i: 22-23; iii: 58-60; iv: 91-93, 95-96; vi: 146-48.

30. For more on reading and imagination see Bérenguier, L'Infortune des Alliances, 323-32.

31. Cerfvol underlines this idea of restraint more than once (I, v: 111-13, 115$16,120,131-32$; II, xiii: 117-18), again repeating Rousseau's advice: "Voulezvous voir votre mari sans cesse à vos pieds? tenez-le toujours à quelque distance de votre personne. Mais dans votre sévérité mettez de la modestie et non pas du caprice; qu'il vous voie réservée et non pas fantasque" (Emile, 865-66). [Do you want to see your husband constantly at your feet? Then keep him always at some distance from your person. But put modesty, and not capriciousness, in your severity. Let him view you as reserved, not whimsical] (Bloom, 479).

32. See Livi, Vapeurs de femmes, 49-58; Hoffmann, La Femme dans la Pensée des Lumières, 111-19; Pierre Darmon, Mythologie de la Femme dans l'Ancienne France (Paris: Seuil, 1983), 85-90.

33. Although Cerfvol can be counted among Rousseau's followers, I am tempted to read a veiled critique of Emile in the following remarks:

Dans le nombre des Livres qui ont paru sous le titre d'Institution, quelques uns n'ont été publiés que pour faire passer, sous prétexte d'instruire les enfants, des systèmes de philosophie dont on était bien aise que les personnes raisonnables se prévinssent. Les leçons qu'on y donne, si elles étaient praticables, ne seraient bonnes que pour celui auquel elles sont adressées, que pour l'être isolé, vivant dans l'Etat de pure nature. Mais vous comprenez, Sophie, que tous vos soins seraient inutiles, si les principes que vous donnerez à vos enfants les excluaient de tous les rangs de la société (II, xvi: 181-82).

[Among the Books which have appeared under the title of Education, some have only been published to disseminate philosophical systems against which reasonable persons must be warned under the pretext of educating children. The lessons given in these books would, if if they were practical at all, would only be suited to the individual to whom they are addressed, to the isolated being who lives in a state of pure nature. 
But you understand, Sophie, that all your efforts would be useless if the principles that you will instill in your children were to exclude them from all ranks of society.]

34. For more on this question see Bérenguier, L'Infortune des Alliances, $311-44$.

35. Alfred Sauvy's summary of Cerfvol's publications on divorce and population confirms that La Gamologie repeats their content in many respects.

36. Nancy K. Miller, "I'I' in Drag: the Sex of Recollection," The Eighteenth Century 22 (1981), 51.

Appendix 1. A Chronological List of Some Instruction Manuals

Gaillard, Gabriel-Henri. Essai de Rhétorique Françoise à l'Usage des Jeunes De moiselles, avec des Exemples Tirés pour la plupart, de nos Meilleurs Orateurs et Poëtes Modernes (Paris, 1746).

Panckoucke, André-Joseph. Les Etudes Convenables aux Demoiselles, Contenant la Grammaire, la Poésie, la Rhétorique, 2 vols. (Lille, 1749).

Dugour, Antoine-Jeudy (De Gouroff). Nouvelle Rhétorique Françoise à l'Usage des Jeunes Demoiselles (1760).

Beaurieu, Gaspard-Guillard. Abrégé de l'Histoire des Insectes, Dédiée aux Jeunes Personnes (Paris, 1764).

Traité d'Etude pour les Jeunes Demoiselles qui Veulent Apprendre la Géographie et l'Histoire (Paris, 1764).

Maugonne, Mlle de. Instruction pour les Jeunes Demoiselles (n.d.).

de Rancy. Essai de Physique en Forme de Lettres à l'Usage des Jeunes Personnes de l'Un et l'Autre Sexe (1768).

Fromageot, (abbé). Cours d'Etudes des Jeunes Demoiselles 8 vols. (Paris, 17721775)

Miremont, Mme de. Traité de l'Education des Femmes et Cours Complet d'Instruction 7 vols. (Paris, 1779-1789)

Wandelaincourt, Antoine-Hubert (abbé). Cours d'Education à l'Usage des Jeunes Demoiselles et des Jeunes Messieurs qui ne Veulent pas Apprendre le Latin 8 vols. (Rouen, 1782).

—. Histoire Universelle, Destinée au Cours d'Education des Demoiselles et des Jeunes Messieurs qui ne Veulent pas Apprendre le Latin (Rouen, 1782).

Genlis, Stéphanie-Félicité du Crest de Saint-Aubain, de. Annales de la Vertu ou Cours d'Histoire (Paris, 1782).

Lezay-Marzenia, Claude-François-Adrien de. Plan de Lecture pour une Jeune Dame (Paris, 1784).

Bauchaint, Principes de la Langue Françoise à l'Usage des Demoiselles (SaintMalo, 1789). 


\section{Appendix 2. A Chronological List of French Conduct Books}

Lambert, Anne-Thérèse Marguenat de Courcelles, marquise de. Avis d'une Mère à sa Fille (Paris, 1727).

Puisieux, Madeleine Darsant de. Conseils à une Amie (Paris, 1749).

- Les Caractères (Paris, 1750-51).

—. Réflexions et Avis sur les Défauts et Ridicules à la Mode (Paris, 1761).

Leprince de Beaumont, Marie. Magazin des Adolescentes, ou Dialogues entre une Sage Gouvernante et Plusieurs de ses Elèves de la Première Distinction (London, 1760).

-. Magazin des Jeunes Dames ou Instruction pour les Jeunes Dames qui Entrent dans le Monde (London, 1764).

Graillard de Graville, Barthélémy. L'Ami des Filles (Paris, 1761).

Epinay, Louise-Florence Tardieu d'Esclavelles, marquise d'. Conversations d'Emilie (Leipzig, 1774).

Reyre, Joseph (abbé). L'Ecole des Jeunes Demoiselles ou Lettres d'une Mère Vertueuse à sa Fille, (Paris, 1786; 2nd ed.).

Genlis, Stéphanie-Félicité du Crest de Saint-Aubain, de. Leçons d'une Gouvernante à ses Elèves (Paris, 1791).

Condorcet, Marie-Jean-Antoine-Nicolas de Caritat, marquis de. Conseils à ma Fille Lorsqu'elle aura Quinze Ans (Paris, 1794).

$\mathrm{M}-\mathrm{W}$. (Roederer). Conseils d'une Mère à ses Filles. 1789 (Paris, 1796).

Wandelaincourt, Antoine-Hubert (abbé). Le Mentor, ou le Livre des Demoiselles et des Jeunes Dames, Ouvrage Destiné aux Personnes du Sexe, et Surtout aux Pensions de Jeunes Demoiselles (Paris, 1808).

Campan, Jeanne. Conseils aux Jeunes Filles (Paris, 1824; 2nd ed.). 